\title{
Hydroclimatic variables associated with El Nino and La Nina events at the Curuá-Una hydroelectric reservoir, Central Amazonia
}

\author{
Roseilson Souza do VALE ${ }^{1,2 *}$, Ana Carla dos Santos GOMES ${ }^{1}$, Raoni Aquino Silva de SANTANA ${ }^{1,2}$, \\ Júlio TÓTA ${ }^{1}$, Scott Dennis MILLER ${ }^{3}$, Rodrigo Augusto Ferreira de SOUSA ${ }^{4}$ \\ 1 Universidade Federal do Oeste do Pará - Instituto de Engenharia e Geociências - Rua Vera Paz, s / n - Salé - 68035-110, Santarém, Pará, Brasil \\ 2 Instituto Nacional de Pesquisas da Amazônia e Universidade do Estado do Amazonas - Programa de Pós-Graduação em Clima e Ambiente - Av. André Araújo, 2936 - Aleixo - \\ 69060-001 - Manaus, Amazonas, Brasil. \\ ${ }^{3}$ State University of New York at Albany - Atmospheric Sciences Research Center - 251 Fuller Road, L317 - Albany, New York, United States of America. \\ ${ }^{4}$ Universidade do Estado do Amazonas - Departamento de Meteorologia, Av. Darcy Vargas, 1200, Parque 10 - 69050-020, Manaus, Amazonas, Brasil. \\ * Corresponding author: roseilsondovale@gmail.com
}

\section{ABSTRACT}

The anomalies of Sea Surface Temperature (SST) influence rainfall and therefore the regime of the rise and fall in the level of the rivers in the Amazon region. The aim of this study was to investigate the influence of the El Nino-Southern Oscillation (ENSO) on hydroclimatic variables and identify the existence of trends on these variables in the Curuá-Una hydroelectric reservoir in the West of the State of Pará. It was used 27 years of monthly precipitation and water flow data to identify possible trends using a non-parametric test (Mann Kendall, $p<0.05$ ), and the standardized precipitation index (SPI) was also calculated. The results indicate a positive tendency of the influence of the ENSO on hydroclimatic variables, although it was observed that the rainfall did not increase over the period of 1977 to 2004. The SPI indicates that extreme events of precipitation are related to El Nino and La Nina and that lower precipitation periods were more intense in the decades of the 80's and 90's. The results show that El Nino events can directly affect the water balance at the micro-watershed of Curuá-Una, as was observed in 2015.

KEYWORDS: drought; precipitation; SPI; level

\section{Variáveis hidroclimáticas associadas com eventos de El-Niño e La-Niña no reservatório hidrelétrico de Curuá-Una, Amazônia Central}

\section{RESUMO}

As anomalias da temperatura da superfície do mar (TSM) influenciam as chuvas e consequentemente o regime de subida e descida do nível dos rios na regiáo amazônica. O objetivo deste estudo foi verificar a influência de eventos El Niño Oscilação Sul (ENSO) sobre algumas variáveis hidroclimáticas e identificar a existência de tendência sobre essas variáveis para o reservatório de Curuá-Una no oeste do Pará. Utilizaram-se 27 anos de dados mensais de precipitação e vazão para identificar possíveis tendências utilizando um teste não paramétrico (Mann Kendall, $p<0.05$ ) e calculado o índice de precipitação normalizado (SPI). Os resultados apresentam tendência positiva da influência do ENOS sobre as variáveis hidroclimáticas, embora não foi observado um aumento na precipitação para o período de 1977 a 2004 . O índice de precipitação normalizado revela que os eventos extremos de seca e precipitação estáo relacionados com eventos de El Niño e La Niña e que os eventos de baixa precipitação foram mais intensos nas décadas de 80 e 90. Os resultados revelam ainda que eventos de El Niño afetam diretamente o balanço hídrico da micro bacia do reservatório de Curuá-Una, como recentemente em 2015.

PALAVRAS-CHAVE: seca, precipitação, SPI, nível 


\section{INTRODUCTION}

About half of the precipitation in the Amazon Basin is tied to evaporation from the Atlantic Ocean (Nobre et al. 1991). Seasonal variations in the location of the IntraTropical Convergence Zone (ITCZ) lead to a strong seasonal cycle in precipitation, with a wet season and heavy rains during JFM and a dry season during JAS (Fisch et al. 1998; Wang and Fu 2007). The seasonal patterns in rainfall precede strong seasonal variations in the flow of rivers, which serve as integrators of hydrological processes within their watershed (Richey et al. 2002; Ronchail et al. 2005a; Marengo and Espinoza 2015). The seasonal cycle in river levels is of fundamental importance in wetland ecological processes (Junk et al. 1989), transport of people and goods, and for decision making regarding creation and operation of hydroelectric dams (Fearnside 2008; 2015).

The sea surface temperature anomalies (SST) in the Pacific and Atlantic Oceans have been tied to variations in the amount and distribution of precipitation and river water levels in the Amazon Basin (Schöngart and Junk 2007; Marengo 2009; Marengo and Tomasella 2012). Hydroelectric power, which can exceed more than $74 \%$ of energy consumption in Brazil, is sensitive to river flow, with low-water periods subject to reduced hydroelectric power generation (ELETRONORTE 2015), increased reliance on thermal power plants (Sauer 2015), and the potential for power rationing. Tolmasquim (2000) concluded that power rationing led to the reduction of industrial growth, a reduction in economic growth, a rise in unemployment, inflation, and inconveniences that deprivation of energy will cause the population. Improved understanding of the relationships between precipitation, river flow, and hydroelectric production in the Amazon Basin is needed to reduce uncertainty in power production and availability. Watersheds and rivers that supply the populations of regions throughout Brazil are at their lowest levels in the last 15 years, with significant impacts on the population (ONS 2015). In the Amazon region, which has the largest total volume of rainfall, drought events were registered in 2005, 2010 and 2015. The aim of this study was to investigate the influence of the El Nino-Southern Oscillation (ENSO) on hydroclimatic variables and identify the existence of trends on these variables in the Curuá-Una hydroelectric reservoir in the West of the State of Pará.

\section{MATERIALS AND METHODS}

\section{Study area and Data collection}

The Curuá-Una dam ('Dark River' in Tupi-Guarani) is located in the Lower Amazon River Basin (41.531,51 km²) in the Curuá-Una River, at the waterfall Palhão (250' S and $\left.54^{\circ} 18^{\prime} \mathrm{W}\right), 70 \mathrm{~km}$ southwest of Santarém, in Pará State (Figure 1). The reservoir was filled in 1977, occupying an area of 72 $\mathrm{km}^{2}$ at the operational level, $30.3 \mathrm{MW}$ capacity, and is $68 \mathrm{~m}$ above sea level (Fearnside 2005). Eletronorte is working on a plan to expand up to $40.3 \mathrm{MW}$, the generation capacity of Curuá-Una Hydropower Plant.

Monthly averages of flow data and precipitation were analyzed for the period of 1977 to 2004 . Data were provided by ELETROBRÁS - Centrais Elétricas Brasileiras SA, responsible for operating the hydroelectric power plant CuruáUna. The Oceanic Nino Index (ONI) was obtained from the website (http://www.cpc.ncep.noaa.gov) of the National Oceanic and Atmospheric Administration (NOAA). The ONI tracks the running 3-month average sea surface temperatures in the east-central tropical Pacific between $120^{\circ}-170^{\circ} \mathrm{W}$ (Nino 3.4 region). To calculate the ONI, scientists from NOAA's Climate Prediction Center calculate the average sea

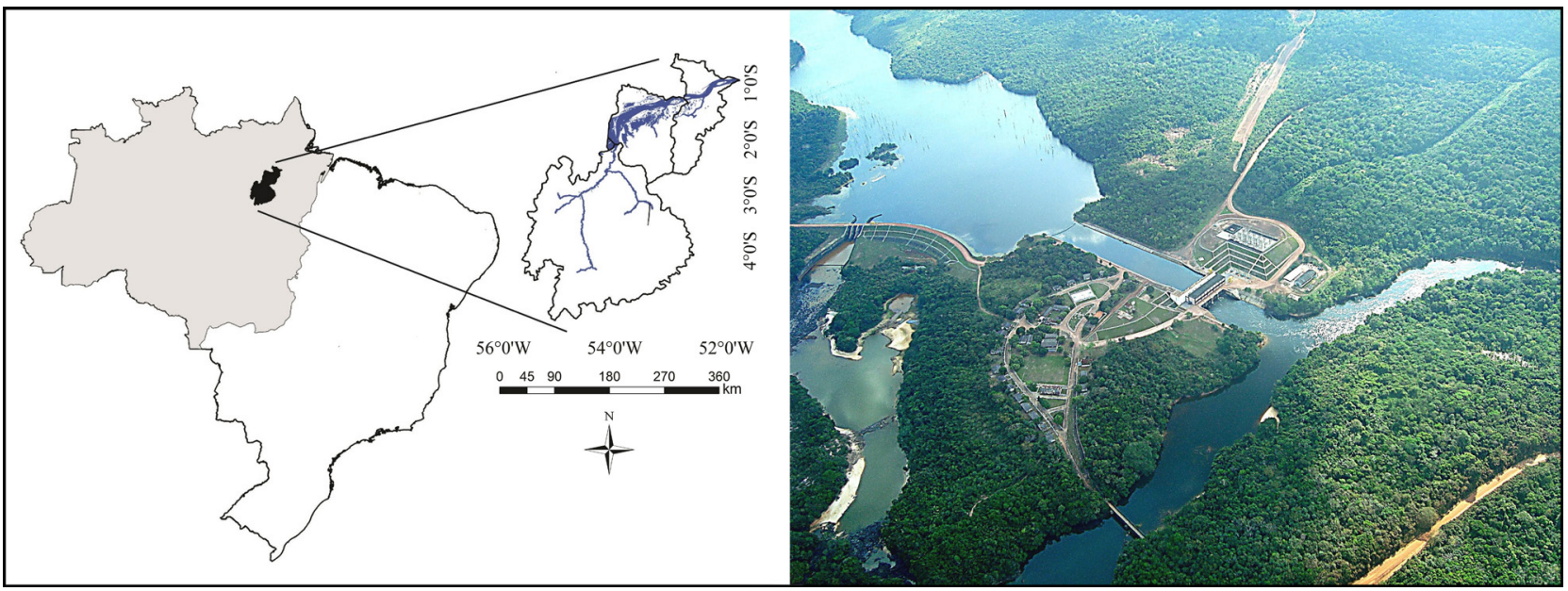

Figure 1. Map with the location of the Lower Amazon river basin (left) and aerial photo of the hydroelectric plant Curuá-Una located $70 \mathrm{~km}$ to the southwest of the city of Santarem in Pará State. This figure is in color in the electronic version. 
surface temperature in the Nino 3.4 region for each month, and then they average it with values from the previous and following months.

This running three-month average was compared to a 30-year average. The observed difference from the average temperature in that region - whether warmer or cooler - is the ONI value for that 3 -month season (NOAA 2016).

\section{Trend in the standardized precipitation index}

The methods used in this study were the standardized precipitation index (SPI) and the Mann Kendall non parametric test (MK). The SPI is based on precipitation alone. Its fundamental strength is that it can be calculated for a variety of timescales (Hayes et al. 1999). The probability distribution function is determined from the long-term record by fitting a function to the data. The cumulative distribution is then transformed using equal probability to a normal distribution with a mean of zero and standard deviation of one so the values of the SPI are actually expressed as standard deviations (Edwards and McKee 1997). According to Goossens and Berger (1986), the MK test is suitable for detecting different climatic changes in meteorological series and it has been widely used in studies of hydrological trends at $5 \%$ significance (Dias de Paiva and Clarke 1995; Marengo et al. 1998; Marengo 2005).

For the SPI analysis we selected a 6-month time scale to build a moving average of the time series of semiannual SPI centered on 12 months (McKee et al. 1993). The semiannual SPI scale is the average duration of events that are important for monitoring the transition period between the rainy and the dry season. This method was used for the Amazon region by Li et al. (2008) and Santos et al. (2013). The monthly SPIs in 6-month time scales were classified and each value corresponds to a value of precipitation SPI (Table 1).

\section{RESULTS}

Despite some possible inferences about the relationship between meteorological phenomena and the temporal trends of rainfall data, it is important to emphasize that the statistical analyses used in this study are conclusive only from the point of view of detection of possible trends. The results presented here should be interpreted as a "starting point", since the precipitation in the Amazon region are is influenced by the complexity of the dynamics and atmospheric teleconnections (i.e., recurring and persistent, large-scale pattern of pressure and circulation anomalies that spans vast geographical areas). (Giannini et al. 2001; Schöngart et al. 2004; Yoon and Zeng 2010).

The total annual rainfall for the period between 1977 and 2004 ranged from $1000 \mathrm{~mm}$ to $2000 \mathrm{~mm}$ in the study region (Figure 2A). The highest annual rainfall values were observed in 1985, 1989, 1999 and 2000, and the lowest annual rainfall was observed in 1981, 1982, 1983, 1987, 1992, 1997 and

Table 1. Standardized Precipitation Index (SPI) classification according to National Drought Mitigation Center (NDMC).

\begin{tabular}{lcc}
\hline SPI values & Class & Probability (\%) \\
\hline$>2$ & Extreme precipitation & 2.3 \\
1.5 a 1.99 & Severe precipitation & 4.4 \\
1.0 a 1.49 & Moderate precipitation & 9.2 \\
\hline-0.99 a 0.99 & Normal & 68.2 \\
-1.0 a -1.49 & Moderate drought & 9.2 \\
\hline-1.5 a -1.99 & Severe drought & 4.4 \\
$<-2$ & Extreme drought & 2.3 \\
\hline
\end{tabular}
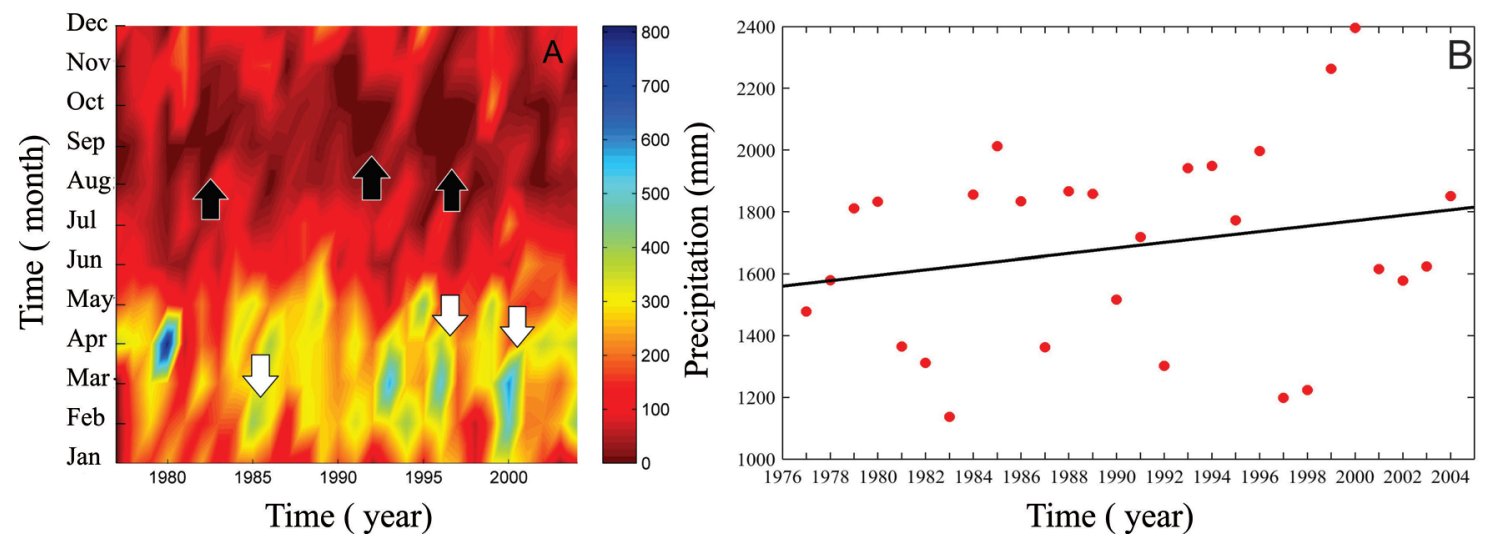

Figure 2. Variability of monthly (A) and annual (B) precipitation data during 1977-2004, with a straight annual trend obtained using the Mann Kendall test (B). Years of El Nino and La Nina are indicated with black and white arrows, respectively. This figure is in color in the electronic version. 
1998. The water flow ranged between $796 \mathrm{~m}^{3} \mathrm{~s}^{-1}$ and $4,432 \mathrm{~m}^{3}$ $\mathrm{s}^{-1}$ with maximum values in the years 1986, 1989, 1996 and 2000 and lower values in 1983,1993, 1998 and 2003. The regression line extracted from the MK test indicates a trend of increase for both precipitation and water flow, however, no statistical significance was found for rainfall and flow which were, respectively, $1.15(p$-value $=0.27)$ and $0.95(p$-value $=$ 0.34 ) (Figure $2 \mathrm{~A}$ and $3 \mathrm{~B}$ ).

The climatic nuances of the region, whose seasonality is well defined between two periods of the year (Figure 4). The first five months, from January to May are the rainiest, and between July to December there is a dry season. We observed periods of severe drought (in red) in 1982, 1989-93, 1995-98 and 2002, and severe rain (in blue) in 1985, 1994, 1996 and
2000. The SPI also revealed that cases of severe drought events occurred in the 90's and these precipitation events were more spread out over the time series.

\section{DISCUSSION}

According to the ONI used by NOAA to identify events of El Nino and La Nina in the tropical Pacific, the years with maximum precipitation, except for 1985 , were moderate to strong years of La Nina. Although the rainfall data are point data, they show that the years of greatest rainfall are directly related to the years of greatest water flow, whether or not there is a delay in the signal. This reveals that these years were more intense not only in the Curuá-Una basin but also in the south-central part of the Amazon basin (Ronchail et al. 2005a;
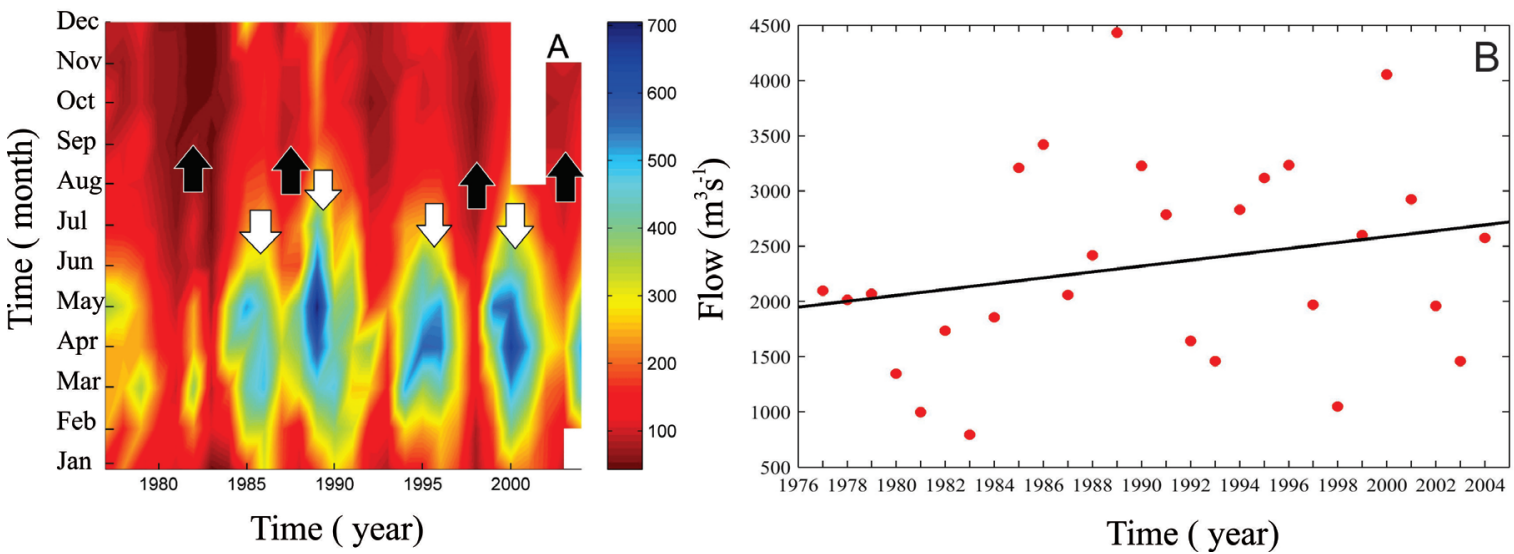

Figure 3. Variability of monthly (A) and annual (B) flow data during 1977-2004, with a straight annual trend obtained using the Mann Kendall test (B). Years of El Nino and La Nina are indicated with black and white arrows, respectively. This figure is in color in the electronic version.

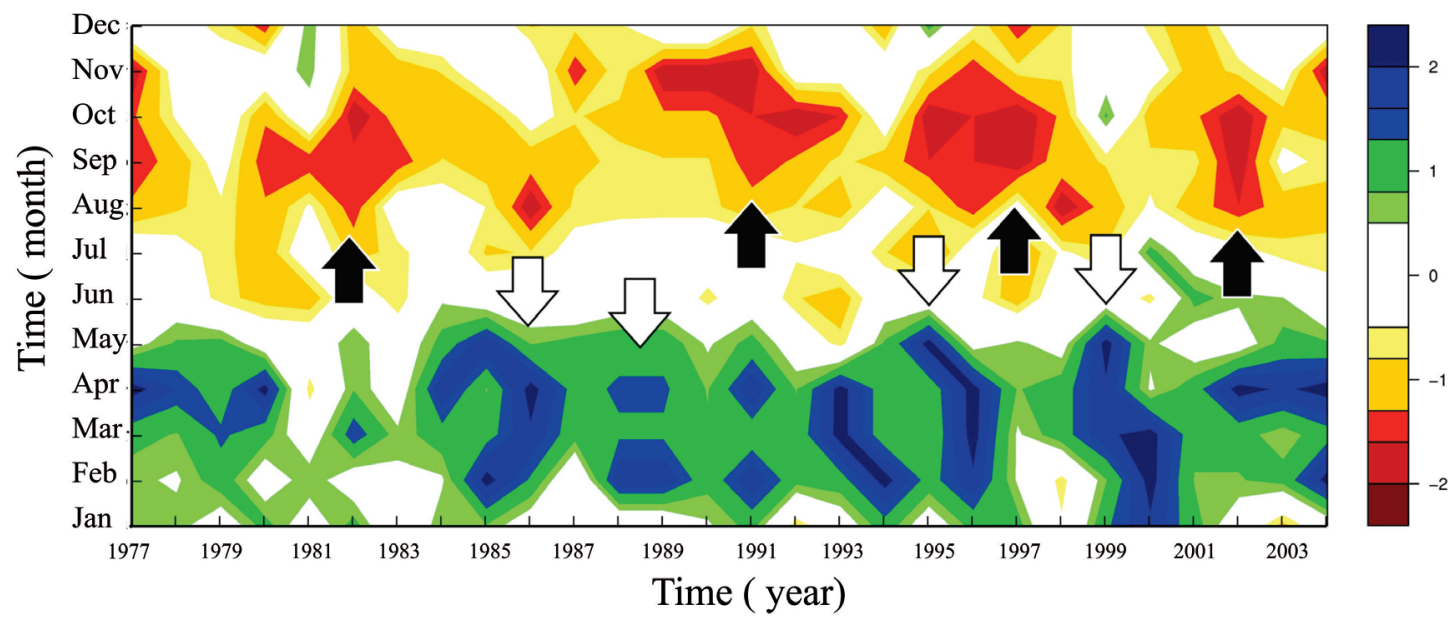

Figure 4. Standardized Precipitation Index (SPI) in the six months time scale for the hydroelectric power plant Curuá-Una in the 1977-2004 period. This figure is in color in the electronic version. 
2005b; Marengo et al. 2011), where the headwaters of the Tapajós and Xingu supply the Curuá-Una basin.

In this study, the years 1983, 1992, 1997 and 1998 corresponded to years of lower rainfall. These years are related to years of strong El Nino events, according to the classification of NOAA. The years of lower rainfall also exhibited effects on the flow of Curuá-Una reservoir. In particular, 1998 was an extremely dry year for much of the Amazon basin, with serious consequences in the transport, health, agriculture and energy and water supply sectors (Marengo et al. 1998; Tomasella et al. 2010; 2013; Marengo and Espinoza 2015).

In our study, MK test showed positive trends for the series of precipitation and flow, however without statistical significance. Other studies on climate and hydrometeorological trends in the Amazon do not demonstrate unidirectional trends in large-scale precipitation or river flows (Marengo and Tomasella 2012; Marengo and Espinoza 2015). According to Dantas et al. (2015) positive trends, but no statistical significance of meteorological variables are related to the absence of long-term data series. The results reveal that years of La Nina and El Nino show above and below average values, respectively. These episodes show the influence of these phenomena on the water balance of the Amazon region, which is confirmed in studies of Marengo (1992) and Marengo and Hastenrath (1993).

The SPI can identify the two extreme drought events in the region caused by the El Nino in 1982-83 and 1997-98. The fact that drought and flooding have occurred over the past decade can be an indicator that the back-and-forth between extreme droughts and floods is becoming increasingly common as natural climate variability and anthropogenic climate change can intensify the hydrological cycle (Gloor et al. 2013).

\section{CONCLUSIONS}

Based on the SPI, it was observed that the rainfall did not increase over the period of 1977 to 2004 . We believed that the absence of significant trends is related to the lack of long-term data series in the Central Amazon region. The micro basin of Curuá-Una reflects the effects of precipitation experienced by the south-central portion of the Amazon basin. It was observed that the SPI indicates that drought and rainfall extreme events are possibly related to El Nino and La Nina events, noting that drought events were more intense in the 80's and 90's. These results can help improve monitoring and forecasts of the water balance components not only for the Curuá-Una micro-basin, but for the entire Amazon basin. Although we can identify the drought indexes and its direct relationship with El Nino and La Nina events, it is known that the Tropical Atlantic also influences the dry season over the region.

\section{ACKNOWLEDGEMENTS}

We thank ELETRONORTE for logistics and access to data, Professor Dr. T. Beldini (UFOPA) for the English revision, S. Souza for technical work, the reviewers by criticism and suggestions to improve the manuscript and FAPEAM and CAPES.

\section{REFERENCES}

Dantas, L. G., Santos, C. A. C., Olinda, R. A. 2015. Trends in annual and seasonal temperature and precipitation extremes in Campina Grande-PB. Revista Brasileira de Meteorologia, 30:423-434.

Dias de Paiva, E. M. C. and Clarke, R. T. 1995. Time trends in rainfall records in Amazonia. Bulletin of the American Meteorological Society, 76: 2203-2209.

Edwards, E. C. and McKee, T. B. 1997. Characteristics of 20th century drought in the United States at multiple time scales, Climatology Report, 97: 1-155.

ELETRONORTE, 2015. (www.eletronorte.gov.br). Access on October 10, 2015.

Fearnside, P. M. 2008. Mudanças Climáticas globais e a floresta amazônica. In: Buckeridge, M.S. (Ed.). Biologia e Mudanças Climáticas no Brasil. RiMa Editora, São Paulo, Brasil, p. 131-150.

Fearnside, P. M. 2005. Do hydroelectric dams mitigate global warming? The case of Brazil's Curuá-Una Dam. Mitigation and Adaptation Strategies for Global Change, 10: 675-691.

Fearnside, P. M. 2015. Amazon Dams and waterways: Brazil's Tapajós basin plans. Ambio, 44: 426-439.

Fisch, G., Marengo, J. A., Nobre, C. A. 1998. Uma Revisão Geral Sobre o Clima da Amazônia. Acta Amazonica, 28:101-126.

Giannini, A., Chiang, J. C. H., Cane, M. A., Kushnir, Y. and Seager, R. 2001. The ENSO teleconnection to the tropical atlantic ocean: contributions of the remote and local SSTs to rainfall variability in the tropical americas. Journal of Climate, 14: 4530-4544.

Goossens, C., and Berger, A. 1986. Annual and seasonal climatic variations over the northern hemisphere and Europe during the last century. Annales Geophysicae, 4: 385-400.

Gloor, M., Brienen, R. J. W., Galbraith, D., Feldpausch, T. R., Schongart, J., Guyot, J.-L., Espinoza, J. C., Lloyd, J. and Phillips, O. L. 2013. Intensification of the Amazon hydrological cycle over the last two decades. Geophysic Research Letters, 40: 1729-1733.

Hayes, M. J., Svoboda, M. D., Wilhite, D. A., and Vanyarkho, O. V. 1999. Monitoring the 1996 drought using the standardized precipitation index. Bulletin of the American Meteorological Society, 80: 429-438.

Junk, W. J., Bayley, P. B., Sparks, R. E. 1989. The Flood Pulse Concept in River-Floodplain Systems. Canadian Special Publication of Fisheries and Aquatic Sciences, 106:110-127.

Li, W., Fu, R., Juárez, R. I. N., Fernandes, K. 2008. Observed change of the standardized precipitation index, its potential cause and implications to future climate change in the Amazon region. Philosophical Transactions of Royal Society B, 363:1767-1772. 
Marengo, J. A. 1992. Interannual variability of surface climate in the Amazon basin. International Journal of Climatology, 12:853-863.

Marengo, J. A. and Hastenrath, S. 1993. Case Studies of Extreme Climatic Events in the Amazon Basin. American Meteorological Society, 6:617-627.

Marengo, J. A.; Nobre, C. A.; Sampaio, G. 1998. On the associations between hydrometeorological conditions in Amazonia and the extremes of the south oscillation. Bulletin de I'Institut français d'études andines, 27:789-802.

Marengo, J. A. 2005. Characteristics and spatio-temporal variability of the Amazon river basin water budget. Climate Dynamics, 24:11-22.

Marengo, J. A. 2009. Long-Terms trends and cycles in the hydrometeorology of the Amazon basin since the late 1920s. Hidrological Processes, 23:3236-3244.

Marengo, J. A., Tomasella, J., Soares, W. R., Alves, L. M., Nobre, C. A. 2011. Extreme climatic cevents in the Amazon basin. Theoretical and Applied Climatology, 107: 73-85.

Marengo, J. A. and Tomasella, J. 2012. Extreme climatic events in the Amazon basin. Theoretical and Applied Climatology, 107: 73-85.

Marengo, J. A. and Espinoza, J. C. 2015. Extreme seasonal droughts and floods in Amazonia: causes, trends and impacts. International Journal of Climatology, 36: 1033-1050.

McKee, T. B., Doesken, N. J., Kleist, J. 1993. The relationship of drought frequency and duration to time scales. In Proceedings of the 8th Conference on Applied Climatology, 17: 179-183.

Nobre, C. A., Sellers, P. J. and Shukla, J. 1991. Amazonian deforestation and regional climate change. Journal of Climate, 4: 957-988.

NOAA, 2016. www.cpc.ncep.noaa.gov. Access on March 24, 2016.

ONS, 2015. www.ons.org.br. Access on September 05, 2015.

Richey, J. E., Melack, J. M., Aufdenkampe, A. K., Ballester, V. M., and Hess, L. L. 2002. Outgassing from Amazonian rivers and wetlands as a large tropical source of atmospheric CO2. Nature, 416:617-620.

Ronchail, J., Bourrel, L., Cochonneau, G., Vaucehl, P., Phillips, L., Castro, A., Guyot, J.-L., Oliveira, E. 2005a. Inundations in the Mamoré basin (south-wetern Amazon - Bolivia) and seasurface temperature in the Pacific and Atlantic Oceans. Journal of Hydrology, 302: 223-238.
Ronchail, J., Bourrel, L., Cochonneau, G., Vaucehl, P., Phillips, L., Castro, A., Guyot, J.-L., Oliveira, E. 2005b. Discharge variability within the Amazon basin. Climate variability and Change Hydrological Impacts. IAHS Publ, 296:21-29.

Santos, T. S. Gomes, A. C. S. Coutinho, M. D. L. Silva, A. R. Castro, A. A. 2013. Análise de eventos extremos na região amazônica. Revista Brasileira de Geografia Física, 6: 1356-1370.

Sauer, I. L. 2015. A gênese e a permanência da crise do setor elétrico no Brasil. Revista USP, 104: 145-174.

Schöngart, J., Junk, W. J., Piedade, M. T. F., Ayres, J. M., Hüttermann, A., Worbes, M. 2004. Teleconnection between tree growth in the Amazonian Floodplains and the El Nino-Southern Oscillation effect. Global Change Biology, 10:683-692.

Schöngart, J. and Junk, W. J. 2007. Forecasting the Flood-Pulse in Central Amazonia by ENSO-Índices. Journal of Hidrology, 335:124-132.

Tolmasquim, M. 2000. As origens da crise energética brasileira. Ambiente \& sociedade, 6: 179-183.

Tomasella, J., Borma, L. S., Marengo, J. A., Rodriguez, D. A., Cuartas, L. A. Nobre, C. A. and Prado, M. C. R. 2010. The droughts of 1996-1997 and 2004-2005 in Amazonia: hydrological response in the river main-stem. Hydrological Process, 25: $1228-1242$.

Tomasella, J., Pinho, P. F., Borma, L. S., Marengo, J. A., Nobre, C. A., Bittencourt, O. R. F. O., Prado, M. C. R., Rodriguez, D. A., Cuartaz, L. A. 2013. The droughts of 1997 and 2005 in Amazonia: floodplain hydrology and its potential ecological and human impacts. Climatic Change, 116: 723-746.

Wang, H., and Fu, R. 2007. The influence of Amazon rainfall on the Atlantic ITCZ through convectively coupled Kelvin waves. Journal of Climate, 20: 1188-1201.

Yoon, J. H. and Zeng, N. 2010. An atlantic influence on Amazon rainfall. Climate Dynamics, 34: 249-264.

Recebido em 12/01/2016

Aceito em 30/03/2016 